\title{
Complete nucleotide sequence of a strain of cherry mottle leaf virus associated with peach wart disease in peach
}

\author{
Tefera A. Mekuria $\cdot$ Keri L. Druffel • \\ James Susaimuthu $\cdot$ Kenneth C. Eastwell
}

Received: 14 December 2012 / Accepted: 11 March 2013/Published online: 7 May 2013

(c) The Author(s) 2013. This article is published with open access at Springerlink.com

\begin{abstract}
The complete nucleotide sequence and genome organization of a peach virus isolate from a naturally infected peach tree showing typical peach wart-like symptoms on the fruit surface was determined and compared to sequences of members of the family Betaflexiviridae. The genome consists of 7,987 nucleotides, excluding the poly-A tail, and has four open reading frames (ORFs). Analysis of the whole genome and putative proteins encoded by each ORF revealed greatest sequence similarity to a cherry isolate of cherry mottle leaf virus (CMLV). The two isolates have similar genome organizations and share 88 and $93 \%$ homology in their corresponding products of the replicase and coat protein genes, respectively. CMLV has been reported from several
\end{abstract}

The nucleotide sequences presented in this report were deposited in the GenBank database under accession numbers KC207480 and KC241881.

Electronic supplementary material The online version of this article (doi:10.1007/s00705-013-1698-3) contains supplementary material, which is available to authorized users.

T. A. Mekuria · J. Susaimuthu · K. C. Eastwell ( $\square)$

Department of Plant Pathology, Washington State University-

I.A.R.E.C., 24106 North Bunn Road, Prosser, WA 99350, USA

e-mail: keastwell@wsu.edu

K. L. Druffel

Department of Plant Pathology, Washington State University,

P.O. Box 646430, Pullman, WA 99164-6430, USA

Present Address:

K. L. Druffel

Department of Plant Pathology, University of Florida-GCREC,

14625 County Rd 672, Wimauma, FL 33598, USA
Prunus spp. and may be associated with peach wart-like disease symptoms on peach fruit.

Peach wart disease (PWD) is characterized by hard, wartlike outgrowths on the fruit surface [5]. Because PWD is graft transmissible, a viral agent has been assumed [5]. A peach tree (Prunus persica cv. Elberta) exhibiting peach wart symptoms (Fig. 1) was tested with a nested RT-PCR assay that detects members of the genera Trichovirus, Foveavirus, and Capillovirus [4]; the test yielded amplicons with sequences similar to that of cherry mottle leaf virus (CMLV, genus Trichovirus, family Betaflexiviridae). CMLV infects several species of Prunus and can be vectored by eriophyid mites, Eriophyes inaequalis [9]. RTPCR assays of the PWD tree using virus-specific primers (Table S1) for other viruses known to infect peach yielded negative results.

To obtain additional sequence information, sequences from the $3^{\prime}$ region were amplified as described previously with an adapter primer [3] and CMLV-specific primers (Table S1). Products were ligated into $\mathrm{pCR}^{\circledR} 2.1$ (Invitrogen) and sequenced. Rapid amplification of cDNA ends was used to obtain the $5^{\prime}$ terminus of the RNA (5'-RACE; Invitrogen) with primers designed from the most upstream sequence (Table S1). Sequences were edited and assembled from at least eight overlapping fragments using CLC Main Workbench version 6 (CLC bio, Muehltal, Germany). Multiple sequence alignments were performed with Clustal W [11].

It is possible that a single agent or mixture of agents could cause PWD. In order to ascertain the presence of additional viruses in the original PWD-affected peach, total RNA from this source was subjected to deep sequencing. Multiplexed 50-bp single-end Illumina sequencing 


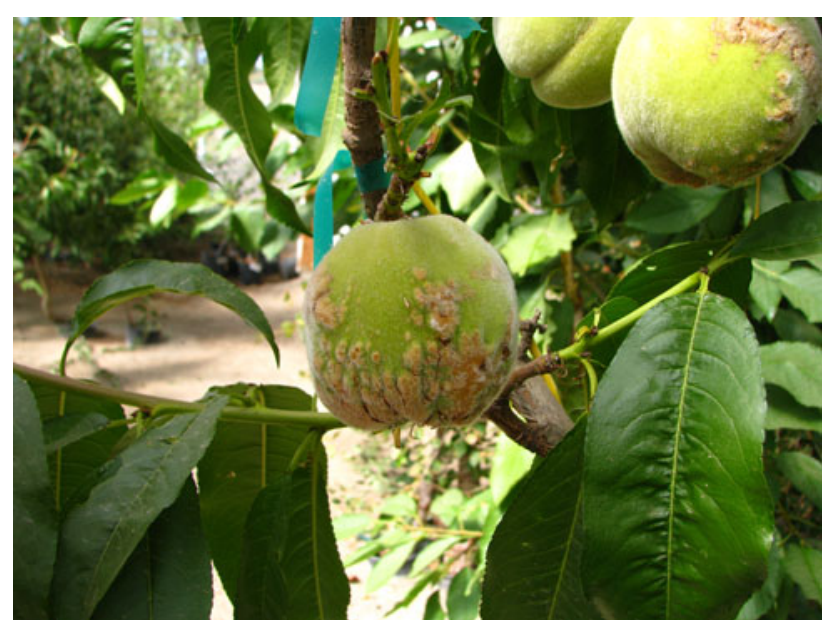

Fig. 1 Peach tree (Prunus persica cv. Elberta) expressing peach wart disease (PWD) symptom on fruits. The tree is infected with cherry mottle leaf virus strain 95CI215 (GenBank KC207480)

generated a total of $15,702,158$ reads from this sample. The total de novo contigs generated were 26,187, with an average coverage per nucleotide of 1,186 . Any contigs greater than $300 \mathrm{nt}$ were compared to virus sequences in GenBank using the BLAST algorithm, and no signature sequences of viruses or virus-like agents other than CMLV were evident. A 7,998-nt fragment homologous to CMLV was assembled from 190,571 reads, and this virus sequence was $99 \%$ identical to the sequence obtained from primer walking.

The complete genome of the virus isolate from the PWD-affected tree (designated strain 95CI215; GenBank $\mathrm{KC} 207480$ ) is $8,004 \mathrm{nt}$ excluding the poly (A) tract and contains four putative open reading frames (ORFs). Its genome organization is typical of members of the genus Trichovirus (Fig. S1). Phylogenetic relationships to members of the family Betaflexiviridae were determined by the maximum-likelihood method in MEGA5 [10]. The PWDassociated strain 95CI215 (GenBank KC207480) co-segregated with CMLV from sweet cherry (strain SA1162-21; GenBank NC_002500)) (Fig. S2).

In pairwise comparisons between CMLV-SA1162-21 and the PWD-associated strain, the putative amino acid sequence identities of the four ORFs were $88,83,93$ and $82 \%$, respectively, suggesting that the virus sequences represent the same virus species [1]. Hence, the virus from the PWD symptomatic tree is a strain of CMLV. However, ORF3, the putative coat protein coding region of cherry isolate of CMLV-SA1162-21, is 193 aa long [6], whereas ORF3 of the peach isolate CMLV-95CI215 is 260 aa long. To facilitate comparison of the amino acid sequences above, only 193 aa at the C-terminus of the CMLV95CI215 coat protein sequence were used. Sequences of CMLV isolates SA1162-21 and 95CI215 possess upstream potential start codons at positions 6540 and 6539 , respectively. However, the sequence of the cherry isolate is followed by two in-frame stop codons (Fig. S3) that are absent from the peach isolate. Moreover, the upstream start codon at position 6,539 of the peach isolate is in the context of Kozak consensus sequence requirements (A at position -3 and $\mathrm{G}$ at +4 ) for translation initiation [2, 8], which are not satisfied by the corresponding upstream start codon in the cherry isolate sequence or by the downstream start codons of either isolate. The configuration of ORF3 of the cherry isolate was confirmed by sequencing the corresponding region of CMLV cherry strain 8464-2/4 (GenBank KC241881) (Fig. S3). Thus, this sequence variation may represent host-specific adaptation of the virus genome.

The 5'UTR of CMLV-95CI215 shows highest similarity to that of peach mosaic virus $(\mathrm{PcMoV})(83 \%)$ rather than CMLV-SA1162-21 (80 \%). CMLV is taxonomically and serologically related to PcMoV [7]. In contrast, the intergenic region between ORFs 3 and 4 is more closely related to that of CMLV-SA1162-21 (77\% identity) than to that of PcMoV (48 \% identity). The $3^{\prime}$ UTR of CMLV-95CI215 is $98 \%$ identical to that of CMLV-SA1162-21, suggesting that conservation may be critical for virus replication [6].

The association of CMLV-95CI215 with PWD and the absence of additional virus signature sequences suggest that CMLV-95CI215 is the causal agent of PWD. The current study lays the groundwork for developing fulllength infectious clones of the peach isolate to verify the role of CMLV-95CI215 in PWD of peach and to investigate the role ORF3 as a host range determinant.

Acknowledgments This study was supported in part by the Department of Plant Pathology, College of Agricultural, Human, and Natural Resource Sciences Agricultural Research Center Project No. WNP00754, Washington State University, Pullman, WA, 99164-6240. Funding from the Washington Tree Fruit Research Commission is gratefully acknowledged.

Open Access This article is distributed under the terms of the Creative Commons Attribution License which permits any use, distribution, and reproduction in any medium, provided the original author(s) and the source are credited.

\section{References}

1. Adams MJ, Antoniw JF, Bar-Joseph M, Brunt AA, Candresse T, Foster GD, Martelli GP, Milne RG, Zavriev SK, Fauquet CM (2004) The new plant virus family Flexiviridae and assessment of molecular criteria for species demarcation. Arch Virol 149:1045-1060

2. Dinesh-Kumar SP, Miller WA (1993) Control of start codon choice on a plant viral RNA encoding overlapping genes. Plant Cell 5:679-692

3. Eastwell KC, du Toit LJ, Druffel KL (2009) Helleborus net necrosis virus: a new Carlavirus associated with 'black death' of Helleborus spp. Plant Dis 93:332-338 
4. Foissac X, Svanella-Dumas L, Gentit P, Dulucq MJ, Marais A, Candresse $T$ (2005) Polyvalent degenerate oligonucleotides reverse transcription-polymerase chain reaction: a polyvalent detection and characterization tool for Trichoviruses, Capilloviruses and Foveaviruses. Phytopathology 95:617-625

5. Fridlund PR (1967) Symptoms of the peach wart virus in some prunus species and peach and nectarine varieties. Plant Dis Rep 51:42-43

6. James D, Jelkmann W, Upton C (2000) Nucleotide sequence and genome organisation of cherry mottle leaf virus and its relationship to members of the Trichovirus genus. Arch Virol 145:995-1007

7. James D, Varga A, Croft H, Rast H, Thompson D, Hayes S (2006) Molecular characterization, phylogenetic relationships, and specific detection of peach mosaic virus. Phytopathology 96:137-144
8. Kozak M (1999) Initiation of translation in prokaryotes and eukaryotes. Gene 234:187-208

9. Oldfield GN (1970) Mite transmission of plant viruses. Annu Rev Entomol 15:343-380

10. Tamura K, Peterson D, Peterson N, Stecher G, Nei M, Kumar S (2011) MEGA5: molecular evolutionary genetics analysis using maximum likelihood, evolutionary distance, and maximum parsimony methods. Mol Biol Evol 28:2731-2739

11. Thompson JD, Higgins DG, Gibson TJ (1994) CLUSTAL W: improving the sensitivity of progressive multiple sequence alignment through sequence weighting, positions-specific gap penalties and weigh matrix choice. Nucleic Acid Res 22:4673-4680 